\title{
Oral Historians Descend Upon the Midnight Sun
}

\author{
IOHA 2018 Memory \& Narration \\ The XX International Oral History Association Conference, University of \\ Jyväskylä. June 18-21, 2018
}

Kelly Fitzgerald

$\mathrm{T}$ he $20^{\text {th }}$ Biennial international oral history association conference, June 18-21, 2018, was held at the University of Jyväskylä, Finland. This event was hosted by Finnish Oral History Network, University of Jyväskylä, and the Finnish Literature Society. It was fitting to be placed in Finland this year due to the centenary of the 1918 Finnish Civil War and the end of World War I. Over three hundred papers and presentations with four keynote addresses occurred over the three days and representation from over forty-five countries took place. One of the key objectives in attending such large conferences is to meet people from the different fields. There are those who have 'discovered' oral history from a more traditional trajectory such as history and then there are folklorists, memory studies scholars, geographers, librarians \& archivists to name but a few disciplines and areas. The increased participation from Asian countries, in particular, was welcomed and with the 2020 confer-

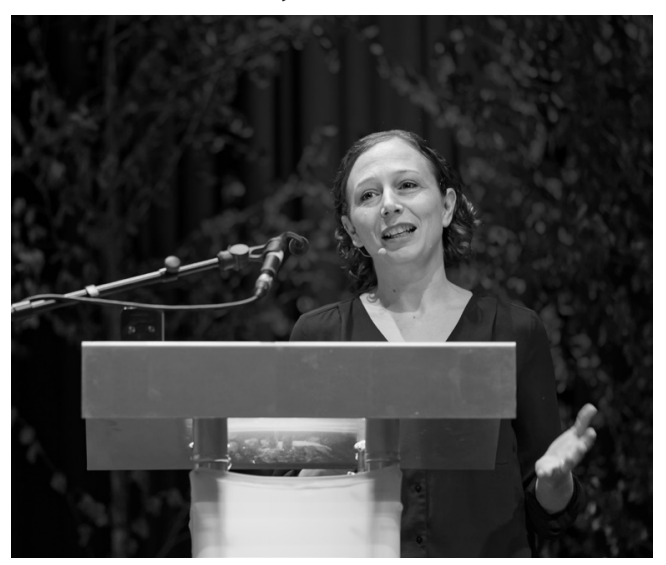

Keynote lecture "Memories of Fiction: Oral Histories of Reading Experiences" by Dr Shelley Trower.

Photograph: Nika Potinkara 2018. international presence.

\section{Historical background in Finland and Ireland}

The establishment of Finnish Oral History Network (FOHN) in 2002 recognised the need for continuous adaptation and developments in the field. Despite Finland holding the leading international position in folklore studies and folkloristics, FOHN is a vital organisation for the academic fabric and culture to flourish. Official recognition of oral history as a distinct discipline may have arrived later but Finnish intuition around collecting and documenting ephemeral information was present earlier such as when the crop failure in 1848 prompted oral interviews to take place in the country. Finland in the 1950s and 1960s saw a shift and 
a change in the way oral source material was perceived and analysed. Ireland experienced a similar process with the development of the Oral History Network Ireland becoming incorporated in 2011, an organisation that continues to support a flourishing oral history community across the island.

\section{Culture and memory}

Throughout the conference a number of speakers spoke about the relationship between memory studies and oral history. Paula Hamilton, University of Technology, Sydney, Australia, delivered a remarkable keynote, 'Rethinking Oral History and the Landscape of Memory', at the start of the day drawing the audience in with a lesser known Carole King and Gerry Goffin song from the 1960s, 'He Hit Me (And It Felt Like a Kiss)' performed by The Crystals. It was not difficult after that to follow Hamilton's presentation of women in domestic occupation in Australia and how their narratives may glean a more informative analysis. This demonstrated the nature of memory and the use and value of oral history today. The conversation following this paper enlightened us that in this Anglophone world we lack the nuances that may be found in other languages and cultures, for example, in Finnish they do not literally translate the term 'oral history' but rather the term muistitieto translates as memory based knowledge.

\section{Representations of civil wars and conflicts}

With such an extensive number of parallel panel sessions this report can only comment on a small number of presentations but a crucial observation is that there were many varied approaches and methodologies presented and executed. In my own session 'Oral History, Museums and Archives' Minna Sannikka and Pete Pesonen presented 'Voices of the Finnish Civil War'The Commission of Finnish Labour Tradition, founded in 1960, operates within the Finnish Labour Archives by collecting and preserving oral history and memoirs. This paper was my introduction to the Finnish Civil War that was well represented in a number of papers, in fact civil wars featured heavily throughout the conference. This repository offers a deep insight into the everyday life as it occurred during a time of war. A war in Finnish history, and it is difficult to find a more painful example than this war, which effected Finnish society on every level and in long-lasting ways, some of which can still be observed today. The pain of this period in Finland's story was acutely examined in the panel on 'Silence in memory, silenced memories'. So much around the analysis of collected oral narratives and life writings is focussed on the actual words, what has been spoken, what has been written. It is far more difficult to decipher and understand the strategical silence or silences found within an interview or record. Nkrumah Bankong-Obi's paper on 'Where Have The Griots Gone? Challenges of Documenting Nigerian Civil War History' demonstrated the necessity of oral records in order to shed light on complex struggles such as what happened during the Nigeria /Biafra War, 1967-1970, particularly in the early days before international coverage took place due to the refugee crisis that resulted from the war. In order to recover voices of the Ogoja Province that are not necessarily reflected in the political record. Silence was also a crucial element in Tomás Mac Conmara's paper, 'Always in the human consciousness of the people: The Irish War of Independence: Violence, vernacular social memory and history' as he demonstrated that despite the lack of these events becoming a part of the family narrative they were not distant memories to those that suffered as a result of the war. 
Wars do not only affect those in direct combat and the source material that oral historians engage with allow a much broader understanding of further aspects in society. This was expressed in Tiina Lintunen's, University of Turku, and Marianne Junila's, University of Oulu, paper, 'Experiences and narratives - the Civil War of young White women'. Exploring the private lives of civilians during the war demonstrates a dynamic development to military histories where social and individual problems arising out of armed conflict may be examined. Erin Jessee's, University of Glasgow, research on 'Conceptualizing trauma in the aftermath of the 1994 Rwandan genocide' further progressed understandings on the deep and lasting effects of war and extreme violence.

Two presentations that dealt with the impact of the Finnish Civil War and how its impact on society in the twenty-first century were Pertti Anttonen's, University of Eastern Finland paper on 'Master Narratives and Counter-Narratives Revisited: On the Political Heritage of Finnish Civil War in Light of the Controversy over Anniversary Coin Series in Spring 2017' and aspects from Pauliina Latvala-Harvilahti, Riina Haanpää, Niina Naarminen, and Laura Seesmeri's poster on 'Personal and Shared Narratives on Living in Unesco's World Heritage Sites in Finland' that included the Living Suomenlinna project which examines place attachment from the viewpoints of cultural heritage studies and landscape studies. Their oral history interviews cover themes from memories of everyday life and places on the island(s) to the local prison camps of the Finnish Civil War. Kati Kallio's, Finnish Literature Society, work on 'Narrating wars and battles in songs: history and emotional resilience' brought me back to a folkloristically comfortable zone.

\section{Folklore, oral history and more}

This brings me to a final thought on this excellent conference and that is the need for further interdisciplinary discussions. As a folklorist, I found myself listening to discussions that could clearly benefit from the contributors employing a deeper engagement with folklore studies. This is not to detract from the work that is being carried out but I will continue to think of ways to facilitate such discussion.

After all the scholarly debates and discussions took place, the conference dinner on a central lake during Midsummer will not be soon forgotten. The conference participants boarded the boats that brought us to our final destination, a spectacular hour-long sail on Lake Päijänne; a truly magical journey, and dinner was held at Juurikkasaari. Thank you, Jyväskylä, you lived up to all expectations.

Dr Kelly Fitzgerald is an Assistant Professor in the School of Irish, Celtic Studies and Folklore in University College Dublin. 